\title{
PROBLEMI PROSTORNOG UREDJENJA PRIVREDNO NEDOVOLJNO RAZVIJENIH PODRUČJA BOSNE I HERCEGOVINE
}

\author{
Milos D. Miß̌kovic*
}

IZVLEČEK

UDK 911.3:711.2 (497.15)

Po sprejetih kriterijih ima $43,7 \%$ teritorija Bosne in Hercegovine status ekonomsko nezadostno razvitega obmoxja. Avtor prikazujc glavne probleme prostorske ureditve.

ABSTRACT

UDC 911.3:711.2 (497.15)

PROBLEMS OF SPATIAL ORGANIZATION OF THE UNDERDEVELOPED REGIONS OF BOSNIA AND HERZEGOVINA

The status of economically underdeveloped regions by accepted criteria has $43,7 \%$ of Bosnia and Herzegovina. The author states main problem of spatial organization of those regions.

Po postojecim kriterijima gotovo polovina naše zemlje ima status privredno nedovoljno razvijenih pedruxja obuhvatajuci tri SR - Bosnu i Hercegovinu, Crnu Goru i Makedoniju te SAP Kosovo ili sa stalno prisutnim nesaglasjem o tome izmedju razvijenih i nerazvijenih dijelova zemlje. Nerazvijeni u prvi plan isticu kao kriterij druStveni proizvod po stanovniku, jer on više umanjuje njihovu razvijenost, a razvijeni se opredjeljuju za osnovna sredstva po stanovniku i relativnu zaposlenost, jer im ovo više odgovara.

Jedan broj istaknutih ekonomista vec godinama istixe da, uzme li se u obzir granična vrijednost izvjesnih kriterija - nacionalni dohodak po stanovniku, osnovna sredstva po stanovniku i broj zaposlenih na 1000 stanovnika, i razvijene republike - Hrvatska, Slovenija i dio Srbije bez Kosova imali bi svoja nerazvijena podruxja. Predlagano je, da se po opsttinama u Citavoj zemlji utvrdi stepen nerazvijenosti, da se takvi dijelovi zakonski utvrde i tek da se na osnovu toga ostvaruju prava na podsticajna sredstva. Ovako izvrŠena diferencijacija na nerazvijene i razvijene omogucila bi svrsishodnije ulaganje sredstava iz razlixitih izvora $\mathrm{i}$ iskljuxilo trosenje ovih sredstava za neproduktivne svrhe vodecih gradova republika i pokrajina te opłtinskih centara.

* Dr.,izr.prof., Odsek za geografijo PMF, 71000 Sara jevo, Vojvode Putnika 43, YU. 
$\mathrm{Na}$ teritoriji SR BiH privredno nedovoljno razvijena podruxja su utvrdjena na osnovu slijedećih kriterija:

1. Društveni proizvod ukupne privrede po stanovniku.

2. Nacionalni dohodak po stanovniku.

3. Stepen zaposlenosti stanovništva - broj zaposlenih u društvenom sektoru na 1000 stanovnika.

4. Vlastita kalkulativna sredstva za opstu i zajednixku potrošnju.

Tako imaju status nerazvijenih opstine kod kojih dostignuti nivo razvijenosti mjeren sa tri od cetiri pokazatelja, od kojih je jedan društveni proizvod ukupne privrede, ne prelazi granißnu vrijednost od $75 \%$ prosjeka Republike. Na osnovu ovakve kvalifikacije status nerazvijenih ima 46 opština (43,7\% teritorija i 35,7\% stanovništva SR BiH): Bijeljina, Bosanska Krupa, Bratunac, Busovaca, Cazin, Čelinac, Duvno, Fojnica, Graðanica, Gradacac, Grude, Hadžici, Kalesija, Kiseljak, Kladanj, Ključ, Kotor Varos, Laktaß̌i, Lištica, Lopare, Ljubuški, Nevesinje, Odžak, Orašje, Posušje, Prnjavor, Prozor, Rudo, Sanski Most, Skender Vakuf, Srebrenica, Srebrenik, Šekovici, Teslic, Tešanj, Velika Kladusa, Zvornik i Žep̌e. Uzme li se u obzir i tendencija opadanja broja stanovnika u 35 opština BiH i uvjet da granična vrijednost za društveni proizvod ukupne privrede po stanovniku ne prelazi $90 \%$ republickog prosjeka, tretman privredno nedovoljno razvijenih opština u 1989. i 1990. proširio bi se na joß̌ osam opక̌tina: Foča, Kalinovik, Kreševo, Livno, Mrkonjic Grad, Rudo, Rogatica, Šipovo i Trnovo. Pregled stepena razvijenosti opština $\mathrm{BiH}$ ilustruje sledeća tabela $-\mathrm{SR} \mathrm{BiH}=$ 100,0 .

Društveni
proizvod po
stanovniku
1987

do $35 \%$

$35,5-50,0 \%$

$50,5-75,0 \%$

75,5-100,0\%

$100,5-120 \%$

više od $120,5 \%$

Opština

Nacionalni
dchodak po
stanovniku
1987

3

8

29

34

12

23

109

$\begin{array}{ll}\text { Stepen } & \text { Kalkul. } \\ \text { zaposlen. } & \text { prihodi } \\ \text { stanovnika } & \text { opština } \\ 1987 & 1986\end{array}$

1

29

46

14

19

109

Iz priložene karte je vidljivo, da privredno nedovoljno razvijene opštine $\mathrm{BiH}$ obrazuje pet karakteristično razmještenih skupina - dvije u južnom i tri u sjevernom dijelu Republike, dakle, ima ih u svim prirodnim i drustveno-ekonomskim cjelinama. Iznenadjuje činjenica da opština sa ovakvim društvenim i ekonomskim statusom ima i u peripanonskom dijelu BiH, bosanskoj posavini. Teško je prihvatiti zbilju da ovoj skupini pripada i plodna Semberija koja se gotovo citava nalazi u okviru opstine Bijeljina. 
Koncipiranje strategije našcg poratnog razvoja i ustvarivanje odgovarajućih ciljeva je dobro poznato. Uzme li se u obzir i naslijedjeno stanje, treba istaci, da su dinamiku drustveno-ekonomskih i prostornih promjena otežala velika ratna razaranja i ljudske žrtve za vrijeme velikih bitaka tokom NOR-a na teritoriji BiH. BiH je na ovaj nacin izgubila oko 174000 svojih gradjana, bez lica poginulih u NOB. Šteta u industriji i rudarstvu procijenjena je na 2.511.419.066, a sumarstvu 6.696.421.109 dinara. Na teritoriji $\mathrm{BiH}$ je uništeno oko $450 \mathrm{~km} 2$ mlade sume, $70 \%$ stornog fonda. Poruseno je 32 000 zgrada u gradovima, ošteceno oko 41000 . Posebno su težko stradala sela: uništeno je 323500 stambenih i privrednih zgrada, a broj oštecenih seže do 150.000 . Posredne stete je teško procijeniti. Ovakvu destrukciju u društveno-ekonomskoj i prostornoj strukturi teß̌ko je bilo sanirati. Prioritet je dat teškoj industriji, bitnim elementima tehnicke infrastrukture i urbanim centrima.

Za djelotvorno funkcionisanje politike prostornog uredjenja veoma je znakajna njegova intelcktualna i zakonodavna pozicija. Ova druga oživotvorena je 1974. godine donosenjem Zakona o prostornom uredjenju ali je i dalje djelatnost prostornog planiranja institucionalno osta!a neizgradjena i kadrovski nepotpuno profilirana. Suviకno je isticati da je i za ovu djelatnost potrebna Siroka naučna baza. Za ilustraciju zakonođavne manjkavosti neka posluži i ovaj primjer. Članom 268. Zakona o prostornom uredjenju iz 1974. predvidjeno je da radna organizacija koja se registruje za izradu prostornih planova mora imati najmanj sest lica sa visokom spremom, od kojih su najmanje dvojica arhitekti. U novom Zakonu o prostornom uredjenju iz 1987. u氏inise se veliki pomak - preciznije se odredjujc profesionalna struktura zaposlenih u organizaciji udruženog rada za izradu prostornih planova: dva lica treba da budu inženjeri arhitekture, dva gradjevinarstva (za saobraćaj i vodoprivredu), inženjer poljoprivrede i diplomirani ekonomista. Ostali potrebni stručnjaci se ne pominju.

Nakon analize Prostornog plana BiH za period 1981. do 2000. godine namace se zakljucak da ne postoji cjelovita koncepcija prostorne strukture Republike. Ova se misao u prvom redu odnosi na razradu razvoja vecih gradskih centara i vodeceg grada Republike, diferencijalan pristup analizi urbane mreže u pojedinim dijelovima radi usmjeravanja njihovog razvoja u modele sa stanovista tekucih i buducih funkcija. Proces dekoncentracije gradskih funkcija razliðito je izražen u pojedinim gradskim centrima, provodi se u prvom redu u interesu tih gradova a manje u interesu prilagodjavanja izvangradskog prostora funkciji gradova, njihovog privrednog aktiviranja i stvaranju inicijalnih ciemenata urbane regije sa stanovišta sadašnjih naux̌nih saznanja, ekonomskih i tehničkih mogućnosti. Veoma bi znacajno bilo vec sada umanjiti negativne tokove u urbancj i ruralnoj mreži koji su u suprotnosti sa novim vizijama organizacije prostora. Transformacija geografskog prostranstva u moderno funkcionalno i cstetski organizovanu teritoriju traži i odredjene organizacione predpostavke radi iziade prostornog plana $\mathrm{BiH}$, regionalnih prostornih planova i prostornih planova za opštine. 
Izostala je potrebna elaboracija prostornog uredjenja monof unkcionalnih horoloških cjeiina za poljoprivredu, sumarstvo, turizam i rekreaciju. Izražene kolizije izmedju ovih funkcija bilo bi mudro rjełavati u skladu sa dobro prostudiranim prognozama i Sirim društvenim interesima. Naux̌ne koncepcije za rekultivaciju pojedinih prirodno-teritorijalnih kompleksa krša $\mathrm{BiH}$ prenose se kao dug iz generacije u generaciju i u tom pogledu nije mala odgovornost geografije i geografa. Obilježavajuci četrdesetogodišnjicu Univerziteta u Sarajevu tokom ove godine moralna je obaveza da se uz usmjeren svecarski ton izvrSi analiza doprinosa nauke u ured jenju prostora.

U politicki i ekonomski neizgradjenim medjuregionalnim podjelama rada i integracionim procesima primjerenim vremenu, od Prostornog plana se nije moglo ni ocekivati aktivnost na regionalnoj diferencijaciji prostora. Prepusteno je to u nadležnost zajednicama opština koje u sadašnjim prilikama imaju više funkciju drustveno-politickih zajednica za društveno-politicki rad, manje za ekonomske poslove i poslove prostornog uredjenja. Odlaganje ovog posla nije u korist racionalne regionalne politike i prakse na formiranju mezoregionalne podjele na regije sa profiliranim endogenim i egzogenim funkcijama.

Nadležnosti prostornog planiranja ne iscrpljuju se projektima prostorne organizacije nego podrazumijevaju i uvid u njeno racionalno funkcionisanje. Nepostojanje potrebne koordinacije izmedju društvenog i prostornog planiranja u svim fazama donosenja društvenih i prostornih planova kasnije nanosi velike stete. Primjer za ovo su neke postolimpijske ambicije u turizmu, favorizovanje nekih gradskih centara i nckih opština.

Posiovi prostornog planiranja su od posebnog društvenog interesa. Medjutim, i dalje su u $\mathrm{BiH}$ prostorno i društveno pianiranje institucionalno odvojene djelatnosti; $\mathrm{za}$ poslove društvenog planiranja postoji stalni organ republicke uprave - Zavod za drustveno planiranje a za poslove prostornog planiranja nema stalno radno nadležne ustanove, ti se poslovi odvijaju s vremena na vrijeme.

Naư̌na saznanja iz oblasti uredjenja prostora koja nam difuzijom inovacija prispjevaju iz inostranstva su dragocjena ali bez vlastitih metodoloßkih istraživanja naß̌g prostora i vlastite teorijske podloge necemo imati efikasnu politiku regionalnog razvoja i racionalnog prostornog planiranja.

Poratni vizionarski snovi o brzom tempu razvoja privredno nerazvijenih dijelova zemlje nisu se ostvarili pa stanje kojc imamo danas u tom pogledu nije samo pos!edica svojevremenog kapitalistiðkog sistema. U kojoj mjeri odgovornost ide na neracionalna demografska kretanja i cfikasnost rada? Ako se mogu tražiti i nalaziti razlozi u delikatnosti mijenjanja ekonomske i prostorne strukture planinskih podruxja $\mathrm{BiH}$, 
privredno nerazvijena podruXja peripanonskog oboda svoju sadašnju nedovoljnu privrednu razvijenost mogu zahvaliti višegodišnjoj poziciji u primarnoj raspodjeli, na njihovim je plecima vršena obnova zemlje i industrijalizacije, od 1945. godine cijene poljoprivrednih proizvoda, energije i sirovina regulisala je država.

\section{LITERATURA}

Analiza ostvarivanja politike ravnomjernijeg razvoja Republike i bržeg razvoja privredno nedovoljno razvijenih podruxja u periodu od 1986. do 1988. godine sa ocjenom uslova i moguénosti i mjerama za ostvarivanje politike u ovoj oblasti u 1989. i 1990. godini. SR BiH, Izvrక̌no viječc Skupštine BiH, Sarajevo, 10. novembra 1988.

Društveni plan Bosne i Hercegovine za period od 1986. do 1990. Službeni list SR BiH, broj 39. od 30. decembra 1985.

Dugoroxni društveni plan BiH za period od 1986. do 2000. godine. Službeni list SR BiH, broj 38. od 28. decembra 1985. godine.

Prostorni plan Bosne i Hercegovine za period od 1981. do 2000. godine. Službeni list SR BiH, broj 15. od 28. aprila 1989.

Zakon o prostornom uredjenju, Službeni list SR BiH, broj 13. od 23. maja 1974. Zakon o prostornom uredjenju, Službeni list SR BiH, broj 9. od 17. aprila 1987.

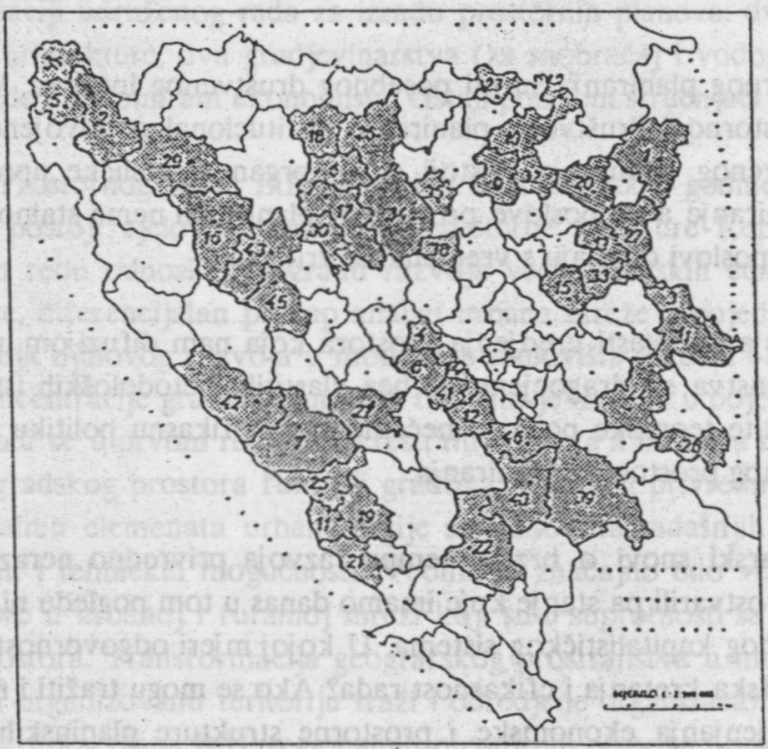




\section{PROBLEMS OF SPATIAL ORGANIZATION OF THE UNDERDEVELOPED REGIONS OF BOSNIA AND HERZEGOVINA}

The status of the economically underdeveloped regions has been given to 46 communities, which is $43,7 \%$ of the territory and $35,7 \%$ of the population. The following are the criteria for determining the degree of development:

1. The social product per capita

2. The national income per capita

3. The degree of unemployment

4. The income used for common expenditure

The status of underdevelopet communities has been given to communities in which the level of development, measured by three of four criteria (including the first obligatorily) does not surpass $75 \%$ of the average of the Republic.

The author analyses in main lines the problems of spatial organization of those regions of Bosnia and Herzegovina pleading for coordination of social and spatial planning and better organization provided by a wider basis of experts. 